\title{
Central Bank Digital Currencies as the Instrument of National Economic Sovereignty Consolidation
}

\author{
Volkova T.G. ${ }^{*}$ Sevryugin Yu.V. Firsova S.N. \\ Kalashnikov Izhevsk State Technical University, Izhevsk, Russia \\ "Corresponding author. Email: sokolova-ng@mail.ru

\begin{abstract}
Subject. The scientific community attention is directed to the issuance of sovereign digital currencies by Central Banks based on blockchain technologies and cryptography.

Objective. Study of the main directions of activity of central banks for creating digital currencies with the purpose to improve the Central Bank of Russia monetary policy. The experience of creating the digital currency, crypto yuan, by People's Bank of China, has been investigated, and mechanisms of its integration into the existing money and credit system have been specified.

Methodology. Comparative analysis and system approach methods, formal logic, empirical study (data comparison, collection, and investigation) are applied, that allowed assessing the directions of digital currencies development.

Conclusions: The Central Bank digital currencies combine the best qualities of private virtual currencies (transaction performance rates, reliability, fixity and irreversibility) and properties of fiduciary money with its centralized emission and state provision. Emission of digital currencies can change the modern banking system architecture crucially, and it will allow solving current issues of monetary and credit policy. An assumption was made that digital currencies can act as an instrument of consolidation of the national economic sovereignty in the conditions of the starting decomposition of the uniform world market into macro regions, growth of global recession risks and finance instability.
\end{abstract}

Keywords: blockchain, distributed registers, private virtual currencies, central bank digital currencies $(C B D C)$, China's National Digital Currency $(D C E P)$, money and credit policy

\section{INTRODUCTION}

Appearance and rapid distribution of a new class of financial instruments in the world, based on the technology of distributed registers of private decentralized virtual currencies and the other crypto-assets, forced central banks of many countries to accelerate the conduct of research in the direction of further transformation of the global finance system. The wide use of virtual currencies as the means of payment can considerably decease the demand for fiduciary money of central banks and decrease the stability of national money systems. For the time being, an issue of creating CBDC (Central Bank Digital Currencies) is under discussion in the bank society. It is possible that some CBDC can make a revolution in global financial system by displacing USD as a backup currency. Of course, this solicitude is shared by specialists from Federal Reserve System, IMF, the World Bank, Bank for International Settlements, and in the other global regulators.

It should be noted that studies of CBDC are superficial so far due to fragmented data and lack of data from open sources. So far, the line of fundamental questions are left without answers. Which will be the interaction between
Central Banks and credit organizations when CBDC appears? Will CBDC solve macroeconomic issues in terms of the separate state? Will the appearance of sovereign CBDSs cause the finance stability growth in the world? Will CBDC be able to change the modern bank system architecture? Can the creation of CBDC be considered the state national strategic priority? Which CBDC will pretend to the role of a future world reserve currency? The world scientific community faces these issues that demand to be investigated.

\section{MATERIALS AND METHODS}

\subsection{Projects of Central Banks for issuance of digital currencies}

Provision of stability of the existing world finance system made in middle January 2020 Bank for International Settlements, BIS to create the work team with the purpose to exchange information about the issuance of centralized 
virtual currencies. It includes central banks of Sweden, Canada, Switzerland, the UK and Japan, and the European Central Bank. Each institution will continue the assessment of "economic, functional and technical options of digital currency issuance by the central bank", and will share its conclusions with the others. It is planned that groups will closely cooperate with Committee on Payments and Market Infrastructures (CPMI), the international developer of payment and clearing standards, and Financial Stability Board (FSB), representing the authority that forms recommendations for the global finance system. The work team has headed by the recently appointed Director of BIS Innovation Center, Benoît Cœuré, and Deputy Chairperson of the Bank of England and Deputy Chairperson of CPMI Jon Cunliffe. [1]

The official opinion of the Bank of England was expressed by the Chief Cashier and the Banknotes Director of the Bank of England Sarah John. In her opinion, CBDC should become the response of central banks to the development of stable coins by large technology companies. Central banks should accelerate development and issuance of digital currencies. Lack of action will cause the regulators to overtake private companies in the field of digital payments [2].

According to Lael Brainard, the member of the U.S. Federal Reserve's Board of Governors, attempts to create private virtual currency payments systems similar to Libra or Facebook, cause illegal financing, loss of confidentiality and instability of the money and credit policy. Nevertheless, Regulatory Cooperation Forum considers the perspectives of issuing its own virtual currency digital dollar based on blockchain networks, used by such assets as bitcoin. These solutions can fulfill almost instant payments at potentially low expenses [3].

The Block published the study stating that 18 central banks already reported on the creation of national CBDCs. Experts studied total 60 countries. In four countries of the world - Senegal, Venezuela, Uruguay and Tunisia - such projects have already been implemented [4].

For example, the Swedish Central Bank jointly with Accenture Consulting Company announced the start of testing digital krone in February 2020. The project will continue for one year based on the isolated test network. It is provided for the users to check the possibility of digital currency storage in e-wallets, and crediting and debiting operations via the mobile application. They will be also able to make payments with smart watches and cards.

In the Russian Federation, intentions to create the national digital currency were announced at the St. Petersburg International Economic Forum in 2017 Later, the Central Bank of Russia offered an idea on reasonability of creating the uniform supra-national digital currency of Russia together with EEU and BRICS partners [5]. For regret, no real steps for this idea implementation have been performed so far. $\mathrm{CB}$ RF straddles the fence in a conservative way, that only proves studying the possibility of launching its own digital currency.

\subsection{Unique features of the People's Bank of China digital currency}

In the race for digital finance system technology leadership, the People's Republic of China is an absolute leader. In our opinion, studying the activity and generalization of experience of People's Bank of China (PBC) on creating the national DCEP (Digital Currency / Electronic Payment - this is exactly the official name of "digital yuan") is an actual scientific task.

According to the Bank for International Settlements classification, DCEP can represent the central bank digital tokens. In centralized systems, token represents a digital means to express the national currency value in the form of electronic money obligation of the Central Bank that can be stored on value storage devices. At this, digital yuan cannot fit in the classic concept of decentralized nonregulated virtual currency. Having the centralized emission, CBDC currency will have the status of the legal means of payment and increase the efficiency of the PRC money and credit policy transmission mechanism. Currency issued by DCEP is centralized and accessible to the public. As the means of payment, it will be used both in retail settlements of physical entities and in interbank and corporate payments

In late December 2019, the head of subdivision of payment and settlement decisions of PRC Changchung declared that China was ready to start testing digital yuan. Digital yuan will circulate based on the existing two-level monetary system. In the highest level, PBC will be directly interacting with commercial banks, emitting digital yuan or taking it out of circulation. Digital yuan-based payment has already passed the functional studies and the setup stage. System declared productivity is 220 thousand transactions per second which is tens thousand times higher than that of Bitcoin with its 7 transactions per second. In 2020, it is planned to implement pilot programs by the largest state banks: China Construction Bank, Industrial and Commercial Bank of China, Bank of China, Agricultural Bank of China, telecommunication corporations Tencent and Alibaba Group, and the international payment system Union Pay. Contractors authorized by PBC should develop software for national digital currency storage, and issue SIM cards with in-built wallets. After the completion of pilot programs, digital yuan will be accrued to the accounts of the PRC commercial banks with the purpose of distribution among the citizens [6].

In order to provide safety of digital yuan transactions, like bitcoin and other virtual currencies, cryptography will be used. Information about transactions will also be ciphered. The Law on Cryptography, adopted by the PRC Parliament, officially came into force on January 01, 2020. The document standardized cryptographic applications and the process of public/private keys management [7]. The new law formed a legislative foundation for creating digital yuan.

For tamper resistance, it is planned to apply the "know your client" (KYC) identity identification 
technology in order to guarantee that the owner spends the funds. PBC and second-level finance institutions will have the possibility to freeze the digital account (wallet) at any moment if they identify suspicious activity.

\subsection{Prerequisites of creating digital yuan and mechanisms of its integration into the existing money and credit system}

We will try to formulate objective reasons of acceleration of PBC work for digital yuan development and introduction into circulation. At the first sight, the answer is rather simple and, as they say, "lies on the surface." It can be supposed that digital yuan is a "Chinese response" to digital currency Libra, that was called initially Facebook Coin. Due to the fact that over 2.5 bl users all over the world are registered in Facebook global social network, in case of successful project implementation, Libra private virtual currency could substantially change transboundary stock flows, be a threat to Chinese payment systems and Chinese national currency. But in September 2019, Libra project was frozen for the indefinite period of time. Under pressure from the side of The United States Securities and Exchange Commission (SEC) strategic partners of Libra Association, such as Viza, Mastercard, PayPal, Stripe, eBay, and the others, announced that they were leaving the project. Despite these news, sad for all virtual currency enthusiasts, PBC not only didn't suspend, but even activated the digital yuan creation work. It should be supposed that there exist other reasons that make PBC implementing its own digital currency at a quickened pace. Let us submit the other objective prerequisites for creating the sovereign digital currency of China. Probably, the first position by importance should be held by the decrease of the Chinese economy growth rates. For example, in 2019, the Chinese GDP growth rate slowed down to the minimal values for the last 30 years and equaled $6 \%$. For comparison, in 2011-2012 GDP of China increased to 9$10 \%$ per year.

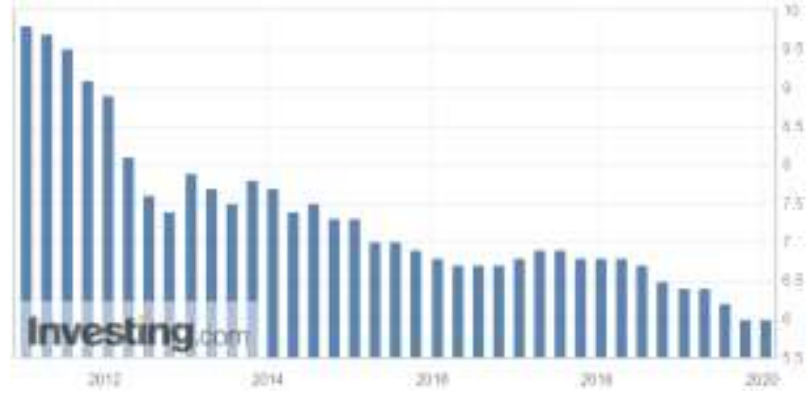

Figure 1 GDP of China dynamics during 2011-2020. [8]

Activity indicators in the industrial sector indicate at the presence of serious problems that are worsened by the COVID pandemic, the burst of which was registered in China in the late 2019. Manufacturing PMI in China fell to the minimal value in February 2020 and equaled 35.7 points vs. 50 points of January 2020, according to the data published by China's National Bureau of Statistics. This is the lowest value for the entire history of its calculations [9].

The second reason for the digital yuan accelerated introduction is the regulation of transboundary operations and counteracting the stock outflow from the country. PRC became the second largest world economy. Business conduct conditions remain highly attractive to global corporations. Cheap labour force, attractive tax conditions, low level of control over environment emissions increase the country investment attractiveness. The leading corporations of the USA, Japan, Korea, European and Asian countries placed their manufacturing facilities here. Despite the PRC economy slowdown and the long-lasting trade war with the USA, growth rates of foreign investment into China don't slow down. According to the results of 2019, foreign direct investment into China increased by $5.8 \%$ up to 941.5 bln yuan. The PBC experts express doubts about the "identity" of foreign direct investments. And, although the practice of "round" foreign investment is spread all over the world, in the most developed countries, this share is much lower than in China. Chinese companies started applying the global expansion practice, and transfer money abroad all over the world. Then, the part of them is transferred repeatedly to China but through the different jurisdictions, in order to use tax benefits and economic privileges as foreign investment. Of course, this is not the transfer of assets abroad in the pure form, but their re-investment. According to Bloomberg, in 2018, around three quarters of Chinese FDI were re-transferred through Hong Kong, the British Virgin Islands or the Cayman Islands that were called "phantom Chinese FDI" in the IMF report [10]. Thus, it can be supposed that digital yuan will be more efficient in preventing the stock outflow from the country. The third reason is connected with the growing geopolitical ambitions of China and build-up of economic, as well as military and political, presence in the countries of South-East Asia, Middle East, and Africa.

For the last decade, China has become a global world creditor. Its finance policy for the provision of loan facilities greatly influences the entire international credit system, forcing the conventional donors (IMF and the World Bank group organizations) to refuse from strict requirements set to the recipient countries.

The study by AidData Laboratory in Wilhelm and Maria College in the USA jointly with specialists from American Harvard and University of Heidelberg in Germany showed that China is the successful competitor to the USA as the largest donor of subsidies and loan facilities [11].

Based on the data of over 5 thousand projects in 140 countries of the world the conclusion was made that for 2000 - 2014 China provided to the countries finance resources in the amount of 362 bln USD, of which $21 \%$ were provided in the form of grants, and the residual amount, in the form of loan facilities. For the same period of time, the USA provided 399 bln USD. Quality differences exist between the financing of the PRC and the 
USA. China mostly provides only repayment financing, and in the USA, gratuitous financial assistance prevails. The PRC credit structure has the prevailing sectors of economy of the recipient countries that contribute to the Chiene economy development. For example, external financing is distributed in the following ratios: energy 134.1 bln USD, transport and logistic - 88.8 bln USD; extracting industry and manufacture, construction - 30.3 bln USD; agriculture and forestry - 10.0 bln USD; other sectors - 74.3 bln USD Thus, the provision of PRC credits are deposits of commercial minerals, land, infrastructure objects, and enterprises. In case if the borrowing country fails to serve and repay Chinese credits, all assets will, possibly, become the property of China.

Created in 2014 Asian Infrastructure Investment Bank with its registered capital of 100 bln USD that also includes Russia, is the "Chinese response" to the World Bank.

China tries to consolidate its influence in Latin America and plans to invest 500 bln USD into this region during the next decade. The Chinese leader Xi Jinping promised to write off debts of the poorest island states of South-East Asia PRC cooperation with the League of Arab States increases. China offers the multi-billion investment to Middle Eastern countries (UAE, Qatar, Egypt, Saudi Arabia, Iran).

One of reasons of staring the trade war against China could become the provision of finance aid to the countries which the USA considers to be "outsiders" and "autocratic" (in particular, North Korea, Afghanistan, Zimbabwe, Nigeria, Angola, Birma, Venezuela, Iron, Cambodia, Etc.).

In these countries, there exists the real danger of be subject to sanction pressure and to lose the possibility to conduct interstate settlements in USD by blocking finance transactions from SWIFT (Society for Worldwide Interbank Financial Telecommunications) side. Similar to decentralized virtual currencies, such as bitcoin, the Chinese DCEP is based on blockchain technology which represents the "e-book with transactions, each of which is ciphered with the use of mathematical formulas. The blockchain system preserves the anonymity of its users and does not control central player, such as a bank or a government [12].

Thus, geopolitical struggle for a redivision of the world between Washington and Beijing becomes more and more desperate, and digital yuan will allow carrying out fast, safe and cheap transboundary transnational and corporate payments.

The fourth reason is a consequence of the previous one. Digital yuan guarantees the absence of finance risks in the implementation of a global trans-continent project "One belt - one way", to which already around 300 bln USD have been spent. Construction of the branched transport and logistic infrastructure through Pakistan, the countries of Central Asia, Africa to Russia and Europe increases the stability of China in relation to geopolitical and economical ambitions of the USA. During 2020-2030 China plans to invest around 1 trln USD into this project.
The fifth reason is that digital yuan is a new means of payment and represents an improved and better-tracked M0 money aggregate (paper money and coins in circulation). This will lead to the considerable decrease of expenses for servicing cash in PRC. And it needs more and more of it. Parallel to the PRC economy growth, wellbeing of its population, its requests and needs for cash provision increase. For example, in 2019, real per capita income in China was 30733 yuans (approximately 4.5 ths. USD), which is higher compared to the similar period in 2018 by $8.9 \%$, as reported by the China's National Bureau of Statistics [13]. For comparison, in 1993, per capita income in China did not exceeds 400 USD. Thus, income increased 11 times for 26 years.

According to Hurun Global Rich List, the China version of Forbes world rating, 799 people in China have fortune worth a billion, and in the USA, this number is only 629 . Total 182 new billionaires appeared in PRC, including Hong Kong and Taiwan, for 2019. Meanwhile, in the USA, the number of billionaires increased by 59 persons only [14].

Digital yuan will be a high liquid means of payment in the national payment system WeChat Pay, which is integrated into the social ecosystem based on WeChat messenger application that belongs to Tencent, and cash settlements in payment system Alipay that belongs to Alibaba Group. Thus, in order to further provide the stable growth of the citizens' income, the efforts should be made, on the one part, in maintaining the economic growth rate, and on the other part, digital yuan should serve as a basis for improving the income distribution scheme which will contribute to the increase of the population consumer capabilities increase.

Sixth, digital yuan introduces the cardinal change in the PRC monetary policy. We suppose that DCEP will circulate simultaneously with cash. Interest accrual under DCEP is not provided, so the cash outflow from commercial banks and shortening of deposits will not happen, most probably. Instead of the conventional partial reservation, used in the banking field, digital yuan provides for 100 per cent provision and, as a consequence, the bank system loses the money multiplier and the possibility to receive income from operations of finance markets.

Seventh, the citizens' payment operations based on digital yuan, collected by the WeChat messenger-based ecosystem, will form a foundation for creating the national social rating system the launch of which is planned by the PRC government in 2020. In 2019, the pilot project has been already launched in Guangzhou. The social rating system is based on the internal digital passport of the PRC citizen, in which the social rating in points is assigned to every citizen.

China Rapid Finance, affiliated with the Chinese giant of industry, Tencent, develops social rating systems [15]. China Rapid Finance assigns the point rating to each citizen of the PRC based on the algorithmic analysis of "numerous digital traces of citizens", such as credit history, large purchase history, court and administrative orders, penalties paid, credit or residential rental 
payment debt, social behaviour, Internet preferences, recommendations of friends from social networks under the principle "friends with high grade automatically increase your grade", etc.

The social rating system will encourage "reliable citizens" and punish the others for non-fulfilled financial obligations. People with high points will be able to: receive credit faster, rent a car without a pawn, receive a tourist visa, pass the fast check-in process VIP customers in Beijing International Airport, and will have the other privileges. Citizens with low rating will be refused in the right to buy a train ticket, be hired, or use the certain state services.

The Chinese company Ant Financial, affiliated with Alibaba, was chosen as the payment system operator. Ant Financial compounding is assessed as 150 bln USD 700 mln Chinese citizens are its customers, and this number exceeds 1 bln of people together with the other countries. Handling capacity of Ant Financial is 256 thousand transactions per second which is three times higher than that of the Visa payment system. Ant Financial has not only the payment system but the largest world money fund "Yu'e Bao" with assets of $\$ 170$ bln, managed by Tianhong Asset Management, the company affiliated with Alibaba. Around $600 \mathrm{mln}$ people, or around $1 / 3$ of Chinese population invested into the fund [16].

It is supposed that digital yuan will be a highly liquid means of payment in WeChat Pay national payment system which is integrated into the social ecosystem based on WeChat messenger belonging to Tencent, and in Union Pay international payment system [17].

Thus, without any doubts, digital yuan will change the lives of the "ordinary" Chinese (and not only Chinese). It will considerably increase the efficiency of PBC fight with legalization and money laundering, terrorism financing, tax dodging, because tracking funds in digital currency is easy.

\section{CONCLUSIONS}

As the result of the study carried out and analysis of the actual material global array, we made the following conclusions:

1. So far, there is no generally acknowledged determination of CBDC due to various concepts serving as the basis for their emission. In our opinion, CBDC represent the Central bank obligations nominated in national currency, having digital representation and able to carry out the main functions of fiducial money: measure of value, payment facility, circulating media and, after a lapse of time, the world money function

2. Despite the financial regulators' restrictions, blockchain economy and decentralized private virtual currencies continue developing. Following the principle "if the process cannot be prohibited, it should be headed", leading world states started considering projects of issuing their own virtual currencies. In the closest years, we will be able to observe the boom of creating national digital currencies by Central Banks.

3. The Russian Government and the Central Bank of Russia hold the negative position concerning private virtual currencies and, for regret, are behind the world finance regulators in developing a project for creating the Russian "virtual ruble".

4. The People's Republic of China is, beyond any doubt, the world leader in the financial system digitalization. People's Bank of China already starts testing the national DCEP. Contrary to virtual currency in terms of the decentralized system, DCEP uses the two-level centralized management system, emission will be controlled by $\mathrm{PBC}$ and issued through the authorized commercial banks. NBC will become a center creating digital currency and approving transactions. Digital yuan combines the best qualities of private virtual currencies (transaction performance rates, reliability, fixity and irreversibility) and fiduciary money with its centralized emission and state provision. DCEP issuance will cardinally change the PRC banking system and will partially solve the money and credit policy issues. It can be assumed that DCEP is the instrument of the national economic sovereignty consolidation, and in conditions of starting decomposition of the uniform global market into macro regions, growth of global recession and finance instability risks, and will allow reaching strategic

Thus, the issue of appearance and functioning of national digital currencies should become the instrument of close attention and discussion of leading economists, representatives of the government finance sector and practicing specialists on Central Banks.

\section{REFERENCES}

[1] P. Baker, 6 Central Banks Form Digital Currency Use Case Working Group. Available at: https://www.coindesk.com/6-central-banks-formdigital-currency-use-case-working-group

[2] V Banke Anglii zayavleno o gonke za tsentrobankov i chastnykh kompaniy $\mathrm{v}$ tsifrovykh platezhakh Available at: https://forklog.com/v-bankeanglii-zayavili-o-gonke-tsentrobankov-i-chastnyhkompanij-v-tsifrovizatsii-platezhej (referral date: 27.02.2020).

[3] FRS SSHA rassmatrivayet perspektivy vypuska svoyey kriptovalyuty - tsifrovogo dollara. Available at: https://mining-cryptocurrency.ru/frs-usarassmatrivaet-sozdanie-cifrovoj-versii-dollara

[4] S. Zheng, At least 18 central banks are developing sovereign digital currencies. Available at: 
[16] D. Kasyanchuk, Kitayskiy muravey. Kak Ant Financial pokoryayet rynok mobil'nykh platezhey?Available at: https://republic.ru/posts/94220

[17] Analiz elektronnoy valyuty tsentral'nogo banka: odna valyuta, dve biblioteki, tri tsentra. Available at: http://baijiahao.baidu.com/s?id=1657114369243931374

[6] Ofitsial'naya tsifrovaya valyuta Kitaya obshchiye kharakteristiki i osobennosti. Available at: https://mining-cryptocurrency.ru/oficialnaya-

kriptovalyuta-kitaya

[7] China Implements Password Law To Pave Way For Digital Currency. Available at: https://www.chinamoneynetwork.com/2020/01/01/chin a-implements-password-law-to-pave-way-for-digitalcurrency

[8] Grafik VVP KNR. Available at: https://ru.investing.com/economic-calendar/chinesegdp-461

[9] Grafik indeksa delovoy aktivnosti v proizvodstvennom sektore (PMI) KNR. Available at: https://ru.investing.com/economic-calendar/chinesemanufacturing-pmi-594

[10] Pochemu pryamyye inostrannyye investitsii $\mathrm{v}$ ekonomiku Kitaya rastut? Available at: https://vestikavkaza.ru/analytics/Pochemu-pryamyeinostrannye-investitsii-v-ekonomiku-Kitaya-rastut.html

[11] S. Khatton, Stantsiya li Kitaya krupneyshim v mire finansovym donorom?Available at: https://www.bbc.com/russian/features-41581844

[12] J. Peter, Denning and Ted G. Lewis Bitcoins Maybe; Blockchains Likely, American Scientist. November - December. 2017. Available at: http://www.ams.org/publicoutreach/mathmoments/mm1 34-bitcoin-podcast

[13] Real'nyy dokhod na dushu naseleniya Kitaya v 2019 godu vyros na 8,9\%. Available at: https://1prime.ru/state_regulation/20200117/830805504 .html

[14] V 2019 godu v Kitaye poyavilos' 182 novykh milliardera, v SSHA - tol'ko 59. Available at: https://nv.ua/biz/economics/kitayskie-milliardery-v-knrza-god-poyavilos-v-tri-raza-bolshe-milliarderov-chemv-ssha-novosti-mira-50072628.html

[15] B. Bram, WeChat Is Watching. Available at: http://m.nautil.us/issue/73/play/wechat-is-watching/ 